\title{
国際的視野をもつ脳神経外科医になるために
}

\author{
村山雄一
}

\section{International Neurosurgeons}

by

Yuichi Murayama, M.D.

from

Division of Endovascular Neurosurgery, Department of Neurosurgery, The Jikei University School of Medicine

Cross-disciplinary international research is always challenging, because in addition to our own area of expertise the researcher must have sufficient knowledge and interest of another field as well. This is a precondition for successful communication and collaboration. The author describes the importance of international collaboration and point of view in the field of Neurosurgery. Young Neurosurgeons should obtain communication skills and understand the way of thinking in the different areas of the specialty for successful clinical research in the field of Neurosurgery.

(Received January 18, 2010; accepted December 11, 2009)

Key words : international, neurosurgeon, education, training

$$
\text { Jpn J Neurosurg（Tokyo） } 19: 395-401,2010
$$

\section{はじめに}

本稿は第 29 回日本脳神経外科コングレス総会におい て伊達 勲会長から拝命した講演を基にした，あくまで 個人的な経験を中心とした主観的内容であることをご理 解いただきたい.

国際的視野をもつということは決して国際的知名度が あることと同義語ではないであろうし，それ自体が目的 ではないであろう。国際的視野は自らが目指すよりよい 医療 (目的)を実現するために国際的な協力，コラボレー ションが必要となり,その過程で養われるのではないか. これは一朝一夕に身につくわけではなく，試行錯誤の中 から必然的に国際協力が必要になったのであり，友好を

目的とした国際活動とは異なるであろう。ある意味では プロフェッショナルとしてのドライな関係のこともあり
うるし，時には研究開発のあり方を巡って激しい議論に なったりすることもありうる。

では自らの目的を実現するため，具体的にどのような プロセスが必要とされるのであろうか. 本稿では，将来 国際的視野をもつた脳神経外科医を目指寸若手医師に何 らかの参考になるよう，個人の経験論を中心に検討した いと思う。これまで取り組んできたプロジェクトは脳血 管内治療に関連した研究プロジェクトが多いが（Table 1) ${ }^{1) ~ 23)}$, 研究プロジェクトの進め方の具体例としてマト リックスコイル開発の経緯を挙げ，必要とされるプロセ スや考え方を提示する。また臨床医として海外勤務を行 う際の課題についても考察する. 
Table 1 Research projects and collaborators ${ }^{1) \sim 23)}$

\begin{tabular}{|c|c|}
\hline 1995-1996 & Doppler guidewire を用いた AVM の研究（慈惠, UCLA) \\
\hline $1995-1997$ & Ion implantation coil の開発 (UCLA, 慈恵, 理化学研究所) \\
\hline 1996 & Micrus coil の開発（Micrus corporation, UCLA） \\
\hline $1996-2000$ & AVM 塞栓用液体塞栓物質 ONYX の開発（MTI，UCLA） \\
\hline $1998-2008$ & 感温性ポリマー TGP の開発（早稲田大学, 慈恵, UCLA） \\
\hline $1998-2005$ & Matrix コイルの開発（UCLA, Boston Scientific） \\
\hline 2003-現在 & 手術室用血管撮影装置の開発（Siemens，慈恵） \\
\hline 2005-現在 & 脳梗塞治療用経頭蓋超音波装置の開発（慈恵） \\
\hline 2008-現在 & 新型ナビゲーション装置の開発（BrainLab，慈恵） \\
\hline 2007-現在 & 脳動脈瘤体積自動測定ソフトの開発（KGT，慈恵） \\
\hline 2007-現在 & 頭蓋内狭窄測定ソフトの開発（KGT，慈恵） \\
\hline 2008-現在 & $\begin{array}{l}\text { コンピュータによる脳血流解析システムの開発 (KGT, Siemens, 慈恵) } \\
\text { 脳動脈塯用ステントの開登 (竓昌) }\end{array}$ \\
\hline 2007-垷仕 & \\
\hline
\end{tabular}

\section{異分野との共同研究開発の進め方 （チームアプローチ）}

著者が取り組んできた bioactive coil 開発の目的は，脳 動脈溜コイル塞栓術の弱点である再開通を克服するため にコイルに生体反応性（機能）をもたせることである. 機能を付加するため機械工学, 再生医療などの基礎技術 の専門家とのコラボレーションが必要であるが，通常， 医学と工学などの異なる分野の専門家同士が最初から理 解し合えることはまれである。専門が違えば，いかにわ れわれが脳動脈瘤治療の重要性を強調したところで, 価 值観の異なる工学の専門家の興味を引くことは困難であ る。そこで相手に興味をもってもらうには，当たり前に 思われるかもしれないが, 誠意と熱意をもって相互理解 できるよう努力するしかない．相手にされなくても食い 下がる。こちらも相手が何に興味があるのか相手の話を よく聞くことも重要である。また相手のもつ技術に対し てわれわれが強い興味を示さなければ協力は得られな い. 結局，人間として興味をもってもらえなければ，医 工連携は絵に描いた餅になる。最終的にパートナーを選 定し, 研究のアウトラインを決定し pilot study を行う。 実験当初は ion implantation という蛋白質をプラチナコ イルに固定する技術で理化学研究所, 表面解析室にお世 話になり, 後に彼らの蘑めもありマトリックスコイルに 応用した生分解性高分子の専門家を探すことになった。 当初は当てもなく，教科書や論文を参考にエキスパート を探したが，相談には乗ってもらえても高額の研究協力 費を要求されるなど, パートナー探しは困難を極めた。 1 年以上かけ, 半ば諦めかけていたところ再生医療の大 御所である Harvard 大学の JP Vacanti 教授の講演会が学 内であることを知り出席した。 そこで偶然 Harvard から
移籍してきた高分子材料の専門家である Dr. Ben Wu と 意気投合し，幸いにも学内所属同士での共同研究がス タートした. 彼とは初対面にもかかわらず, 講演会の後, 深夜まで語り合い, 研究プロジェクトの詳細まで一晚で 一気に決定してしまったが，こうした出会いは待ってい ても誰かが設定してくれることはない.フットワークを 軽くし，とにかく行動しなければ何も始まらない。

\section{データ解析}

基礎実験を通じてコンセプトが正しいか検証する，当 初われわれは ion beam 技術に取り組んでいたが，一定の 効果が確認されたものの，製品化を前提とした際，コス トや量産方法などの課題が残った. Ion beam の専門家に してみれば，その技術を利用してくれるのであれば何も 脳動脈瘤塞栓コイルでなくても人工血管など他分野でも 上く, 対象を限定する必要はない。一方, 脳血管内治療 の立場からは，ion beam でなくとも瘤を修復できる他の 技術でも構わない．研究のための研究であれば継続的な 研究費獲得のため新しい手法への変更は重大なりスクに なるが，実用化を最優先にした場合，迅速な方針変更が 必要となる。結局 ion beam の研究は丸 3 年行ったが, 2 年目後半から別の手法である生分解性高分子の研究も並 行して着手した。

\section{特許出願}

おそらく日本の医科大学では特許申請に関する教育は ほとんぞなされていないであろう。米国でも独学でその プロセスを学んだが，いわゆる TLO あるいは TTO (technology licensing office, technology transfer office) $と$ 
呼ばれる知的財産を管轄する部署が米国大学では充実し ており, TLOのサポートにより研究者が特許のドラフト を書き，そのドラフトを基に弁理士が特許申請の作業を 代行する.すべての医師, 研究者は正式採用の際, 考案 した知的財産 (intellectual property：IP) は大学に帰属す る旨の契約書にサインをする。ちなみカリフォルニア 大学は特許取得数全米第 1 位 (2008 年)の大学であり, そ の特許のもたらすライセンス収入は年間 128 million（約 100 億円）ドルを超える. 本邦における国公私立大学な どの総特許収入が 10 億円程度であることと比較する と, いかに米国大学発の知的財産が産業に結びついてい るか䀞然とし，研究のありかたやひいては国家戦略の違 いを実感した。ちなみに米国特許は US patent web site から誰でもキーワードですでに成立している特許や審議 中の特許を検索することができる．脳血管内治療の分野 では，例えばコイルに付加価值を追加するような同様の アイデアがすでに多くの研究者によって特訴化されてい ることに驚きを覚えた。

特許申請，つまり知的財産を押さえたら，実際に製品 化を目指すため技術移転が可能な企業のサーチに入る. 通常 TLO が全権をもって数十社と交渉し，好条件の企 業と技術移転契約を結ぶ。

企業にプロトタイプの作製を依頼し，最終的な製品の デザインを決定する。

\section{Good Laboratory Practice (GLP) study}

医療機器開発では GLP study と呼ばれる統一規格の 実験手法の下で FDA（米国食品医薬品局）に提出する デー夕を取得する必要がある，GDC 開発当時，UCLA は GLP に適合した研究環境ではなく，著者は GLP study director として UCLA の実験施設を GLP の規格に合致 するよう実験施設および work flow の改良を命じられ た．当初 GLP なるものをまったく理解しておらず，専 門の講習会に参加して実験規格の書類の山と臨床の合間 に格闘することになった，GLP study では standard operative procedure (SOP) と呼ばれる規格に則った実験 を行わなければならず，実験動物の飲料水の品質管理か ら麻酥，実験手技の一つひとつが所定の方式で規定され ている、QA（quality assurance）と呼ばれる第三者的報 告義務のある agent がすべての実験プロセスを監視し， メスの使用方法一つアレンジしただけで protocol violation として指摘を受けることになる(Fig. 1). GLP study は苦痛の伴う仕事であったが，今となっては貴重な経験 であったと思う。

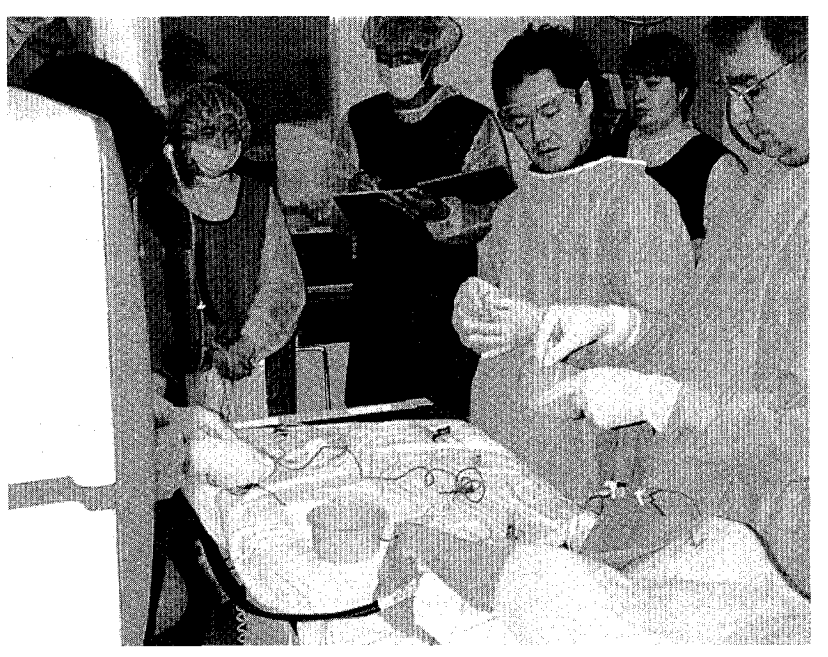

Fig. 1 Matrix animal data collection for FDA submission

\section{グラント申請}

大学で研究する以上, 研究費の獲得は義務でもある. NIH（米国国立衛生研究所）の研究費の中でも R01 と呼 ばれる大型研究費の獲得は一線級の研究施設にとってき わめて重要であり, 研究者にとっても R01 が獲得できれ ば学内での tenure track (永久職) がほぼ保証されること にもなる．日本の科学研究費とは評価のプロセスも制度 も大きく異なり，準備すべき書類は 50 ページを優に超 える。一般に NIH グラントが獲得できれば研究費の一部 を自身の給与に反映することができる，逆にいえば，研 究費の切れ目が縁の切れ目にもなりうる点では非常にシ ビアな制度であうう。また大学でのキャリアアップには, グラントなくして純粋に臨床症例をこなすだけでは困難 である。一般に assistant professor からスタッフとして のキャリアがスタートし， 2 年ごとの人事評価の際にス テップアップしていかなければならない. Assistant professor のランクはStep 1〜3 まであり,一定期間内（通常 7 年）に associate professor に昇任できないと解雇とな る.グラント申請一獲得も個人の努力だけでは外国人に はきわめて困難である，共同研究者の協力はもとより， 縁の下の力持ちとして貢献してくれたのは現地の research assistant たちである. 彼らの多くは医学部進学 を目指す米国人の undergraduate や海外の医学部を卒業 して米国でのレジデントのポジションを獲得することを 目的として渡米している若い医師たちである，彼らの協 力なくして NIH グラントの獲得はありえなかった. 申請 までの数力月は正に寝食を共にするような生活を強いら れ，国籍の異なるメンバーが共通の目的のために協力す る過程こそが国際的な感覚を身につけるうえで貴重な経 


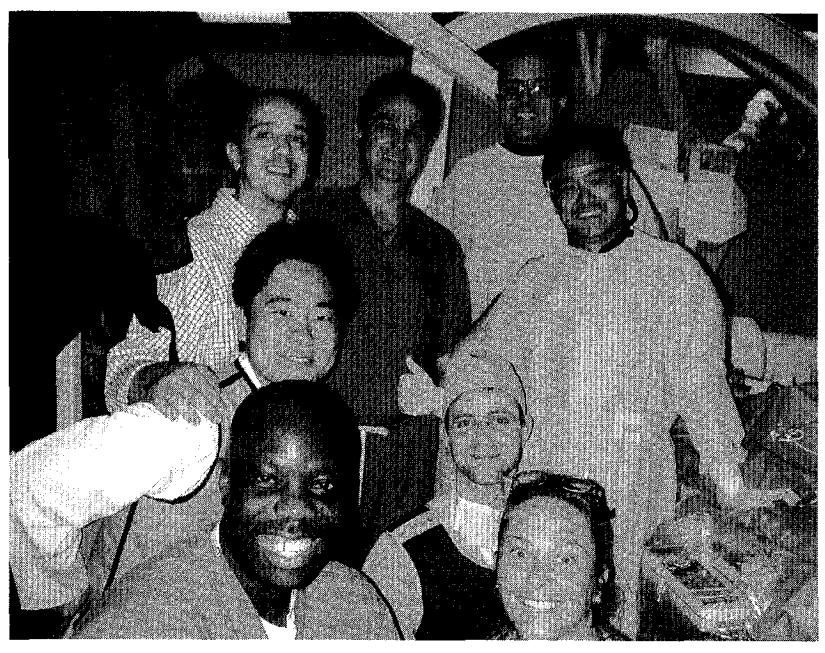

Fig. 2 Successful first Matrix clinical case at UCLA Medical Center

験であったと思う。彼らもその経験をもって自身のキャ リアアップを図ることができ, 現在は UCLA 脳神経外科 のスタッフとして採用されるなど各方面で活躍してい る.

\section{臨床評価（post market study：PMS）}

FDA の認可承認後，米国およびヨーロッパ 20 施設に おいて PMS (post market study) を行うことになった (Fig. 2)。その際，世界各国の医師が UCLA 訪れ実際 にラボでハンズオンの講習会において彼らと手技を行っ たこともよい経験となった。またヨーロッパ各国の医師 の置かれている現状が米国のそれとはまた異なり，各国 それぞれ諸事情があることを学んだ。またPMS の過程 で医療機器開発の諸問題を経験することになる。研究開 発で一定の成果を確認したものの，製品としての評価は いまだ prototype であり, coil friction などの解決すべき 課題も残った。にもかかわらず大学と企業のライセンス 契約が成立すると，製品となったコイルの臨床応用は企 業の marketing 戦略主導となり，われわれ研究サイドの 意見はかき消されてしまった。

いかなる医療機器にも改良すべき点, 適切な使用法が あるが，企業論理は時に安全な医療を行ううえで負の側 面があることを研究者は知っておくべきであり，企業の 論理（利潤第一主義）に迎合してはならない，開発に携 わった研究者こそ, 医療機器の安全性を最優先に考え, 収益重視の企業と時には対峙することも必要である。こ こで重要となるのが IP の確保である．大学が IP を有 し，企業に使用権を有するライセンス契約であれば最悪 の場合, 大学は契約を解除することができる. IP を有し
ない研究開発では企業の暴走を止める術はない．われわ れの再三の指摘により企業は改良モデルの開発に合意 し，2005 年には frictionの改善された Matrix 2 が販売さ れ，2008 年度からは本邦でも使用可能となった。

\section{医師免許の獲得と臨床}

米国をはじめとする海外で臨床経験を積みたいと望む 若手医師は多い.しかしながら, 医䧇免許およびポジショ ンの獲得は容易ではなく, 近年米国でのハードルは高く なる一方である．カリフォルニア州で医師として䛦療に 携わるには，特別な条件下での limited license を手にす る以外, 米国人医師同椂, 米国医師国家試験 (USMLE) に合格する必要がある (一部の州では例外もある). 著者 は幸いにも渡米 3 年目から施設限定の 2011 と呼ばれる カリフォルニア州の特別ライセンスで臨床トレーニング を受けることができたが, attending と呼ばれる診療ス タッフとして指導する立場になり，いよいよUSMLEを 受験せざるを元なくなった. USMLE は基礎医学 Step 1, 臨床医学 Step 2 および日本でも OSCE と呼ばれる実地 試験（CS）に合格しなくては臨床に従事することができ ない. 30 歳半ばで最新の分子生物学や習ったことのない 行動科学などの基礎医学や産婦人科の教科書を開くのは 苦痛以外の何ものでもなく, 普段教育している医学生た ちに家庭教師（?）をしてもらいながら不名誉な落第の 後に何とか合格までこぎ着けた。これらの試験は 1 日 8〜9 時間の長丁場のコンピュー夕試験であり, 可能であ れば学生のうちに取得できればそれにこしたことはな い.ちなみに UCLA 脳血管内治療部での踟床チームは正 に国際色豊かであった. Division chief である Professor Viñuela はウルグアイ出身, Gary Duckwiler は母親が日本 人の米国人, 血栓除去デバイスである MERCI を考案し た Pierre Gobin はフランス人であり，純粋なアメリカ人 はフェローだけであった。患者さんもロサンゼルスの土 地柄からヒスパニック系が多く, 片言のスペイン語も学 ぶ必要があった。

\section{ビザの問題}

おそらく個人の努力ではどうにもならない，しかも最 もハードルの高い問題はビザであろう。いかに米国で診 療および研究を続けたくとも永住ビザ(グリーンカード) がないとその活動は制限され，場合によっては研究ある いは臨床を中断し帰国せざるをえなくなる。このグリー ンカードの取得の際, 国内外の一線級の研究者からの推 
薦状が少なくとも 10 通以上は必要になる. 米国内だけ でなく世界各地に自分を評価してくれる研究者との交流 がなければ当然推薦状を集めることはできない，推薦状 の記載で最も重要なことは，その人材を米国居住させる ことがいかに国益になるかという点である.グリーン カードの申請の過程で米国がいかに外国人（移民）に支 えられ，移民を国の財産（資源）として有効利用してい る国家であるかがわかる。

\section{帰国後}

米国大学勤務で多くのことを学んだが, 欧米諸国の脳 血管内治療におけるシステムの問題点も明確になった。 脳血管内治療は画像診断技術の延長線上で，放射線科主 導で発展してきた技術である。しかし，いくらカテーテ ル手技に長けていても脳動脈瘤をはじめとする脳血管障 害の治療は血管内治療手技だけでは成り立たず，ICU 管 理や出血性合併症に対する包括的な脳神経外科的治療が 必須なのは論を俟たない. 米国では実際の患者管理は脳 神経外科レジデントが担当しているが，以前は彼ら若手 脳神経外科医が脳血管内治療のトレーニングを受けるこ

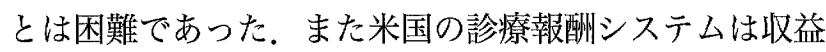
至上主義的な側面があり，施設にもよるが放射線科と脳 神経外科の壁があることにより必ずしも患者にとつて最 良の治療適応が選択されていないこともある。一方，本 邦では脳神経外科医が血管内治療を手がけており，未破 裂脳動脈瘤なども治療だけでなく経過観察を含めた包括 的な治療方針が立てやすい環境であるといえる。そこで 米国では実現困難であった合併症対策や開頭手術にも最 新の imaging technology の長所を取り入れた endovascular operating room のコンセプトを導入した。治療環境を 放射線検查室から手術室へシフトすることに，当初医療 機器メーカーもその将来性には疑問をもっていたが, 最 近では諸外国でも脳神経外科医がクリッピング術だけで なく血管内治療を施行することがトレンドであることも 追い風となり，このコンセプトを導入する施設が増えつ つある (Fig. 3)。とりわけ著者の mentor である東京慈 恵会医科大学 阿部俊昭教授, UCLA Fernando Viñuela 教 授が Charles Drake 教授の下で研讃を積んだカナダ Western Ontario 大学病院でも本システムを導入するこ とになり, 微力ながら協力させていただいた際は不思議 な縁を感じた。

このように単なる欧米至上主義や国粋的な欧米否定で はなく，冷徹に海外と日本のそれぞれの優れている点を 取り込むことが重要であり，本邦からも世界をリードす

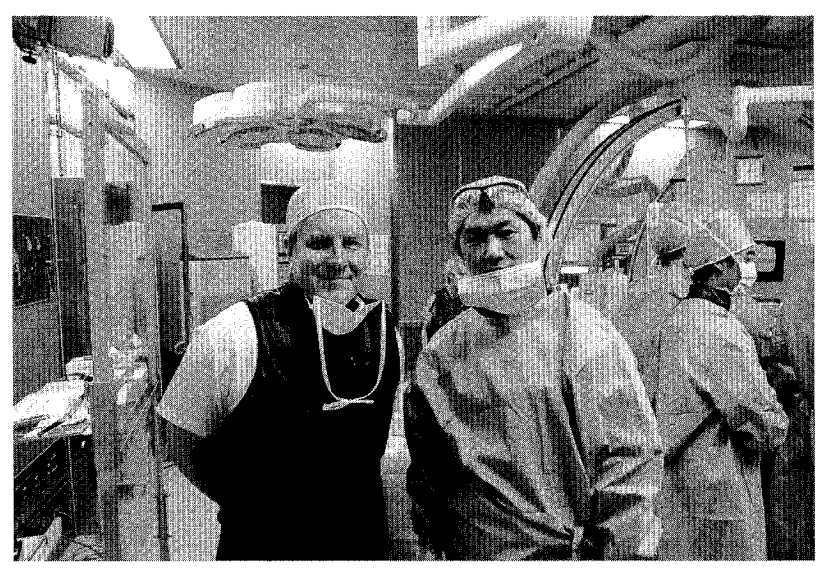

Fig. 3 Dr. Peter Rasmussen from Cleveland Clinic visit Jikei Endovascular OR. They installed same Endovascular OR system in the Cleveland Clinic Hospital.

る臨床研究に取り組む余地は十分あると考光る。

\section{国際的医師になるために必要な要素とは}

当然のことながらある程度の語学力，コミュニケー ション力がなけ机ば相手に自分の考㝋を伝えることがで きないのでこれは最低限必要である。しかし単に流暢な 英語を話す能力が必須なのではない，実際に要求される のは文法力ではなく，自分が考えていることをいかに はっきりとわかりやすく相手に伝えられる能力である.

一般に帰国子女でもないかぎり, non-native speaker で ある日本人が欧米社会にすんなり溶け込むのは容易では なく, 留学当初語学の壁に苦しむ多くの日本人留学生が 孤独感や疎外感を感じるのは当然である。あまり意気込 み過ぎるより純粋に海外での新たな経験自体を楽しむこ とも大切であろう。できるかぎり職場以外のコミュニ テイに参加し友人を作ることが語学や文化の問題をクリ アするうえで大切である，またすでに述べたフットワー ク，他分野（他人）を理解するよう努力することも大切 である。

そして海外を目指す若手医師が忘れてはいけないのは 上司の理解とサポート，さらに同僚の存在によって自身 の海外での活動が支えられている点である.

誰もが最初から業績があるわけはなく，上司がチャン スをくれなければ実績はできない.上司が引き上げてや ろうと思う人材は決して単なるイエスマンではない，真 剣に熱意をもっている若手にはおのずとサポートの手が 差し伸べられるのではないだろうか. 著者は, 慈恵にお ける阿部俊昭教授，UCLA における Fernando Viñuela 教 授の引き上げがなければ決して今の自分はなく，感謝に 
值する上司に恵まれたことが自身の財産と思う。 今後は学内のみならず意欲をもった若手脳神経外科医 が活躍しやすい環境整橵が著者に与えられた課題である と考えているし，これからの世代の若手脳神経外科医に 期待したい.

\section{文 献}

1) Gobin YP, Murayama $Y$, Milanese $K$, Chon $K$, Gonzalez NR, Duckwiler GR, Viñuela F : Head and neck hypervascular lesions: Embolization with ethylene vinyl alcohol copolymer: Laboratory evaluation in Swine and clinical evaluation in humans. Radiology 221:309-317, 2001.

2) Gonzalez NR, Patel AB, Murayama Y, Viñuela F : Angiographic evidence of aneurysm neck healing following endovascular treatment with bioactive coils. AJNR Am J Neuroradiol 26: 912-914, 2005.

3) Irie K, Murayama, Y, Saguchi T, Ishibashi, T, Ebara M, Takao $\mathrm{H}$, Abe $\mathrm{T}$ : Dynact soft-tissue visualization using an angiographic $\mathrm{C}$-arm system: Initial clinical experience in the operating room. Neurosurgery 62 (Suppl 1) : 266$272,2008$.

4) Ishii A, Murayama Y, Nien YL, Yuki I, Adapon PH, Kim R, Jahan R, Duckwiler G, Viñuela F: Immediate and midterm outcomes of patients with cerebral aneurysms treated with Matrix 1 and Matrix 2 coils: A comparative analysis based on a single-center experience in 250 consecutive cases. Neurosurgery $63: 1071-1079,2008$.

5) Jahan R, Murayama Y, Gobin YP, Duckwiler GR, Viñuela $\mathrm{F}$ : Embolization of arteriovenous malformation with Onyx : Clinicopathological experience in 23 patients. $\mathrm{Neu}$ rosurgery 48: 984-997, 2001.

6) Lee D, Yuki I, Murayama Y, Chiang A, Nishimura I, Vinters HV, Wang CJ, Nien YL, Ishil A, Wu BM, Viñuela F : Thrombus organization and healing in the swine experimental aneurysm model. Part I. A histological and molecular analysis. J Neurosurg 107: 94-108, 2007.

7) Murayama $Y$, Usami S, Hata $Y$, Ganaha F, Hasegawa $Y$, Terao T, Abe S, Furuhata H, Abe T: Transvenous hemodynamic assessment of arteriovenous malformations and fistulas: Preliminary clinical experience in Doppler guidewire monitoring of embolotherapy. Stroke 27: 13581364, 1996.

8) Murayama $Y$, Massoud TF, Viñuela $F$ : Transvenous hemodynamic assessment of experimental arteriovenous malformations: Doppler guidewire monitoring of embolotherapy in a swine model. Stroke 27:1365-1372, 1996.

9) Murayama Y, Viñuela F, Suzuki Y, Do HM, Massoud TF, Guglielmi G, Ji C, Iwaki M, Kusakabe M, Kamio M, Abe $\mathrm{T}$ : Ion implantation and protein coating of detachable coils for endovascular treatment of cerebral aneurysms: Concepts and preliminary results in swine models. Neurosurgery 40: 1233-1244, 1997.

10) Murayama Y, Suzuki Y, Viñuela F, Do HM, Massoud TF, Guglielmi G, Iwaki M, Kusakabe M, Kamio M, Abe T: A new surface modification technique of platinum coils by ion implantation and protein coatings for intravascular treatment of brain aneurysms. Nucl Instr And Meth B 127/128: 1015-1018, 1997.

11) Murayama $Y$, Massoud $T F$, Viñuela F: Hemodynamic changes in arterial feeders and draining veins during embolotherapy of arteriovenous malformations : An experimental study in a swine model. Neurosurgery $43: 96^{-}$ $106,1998$.

12) Murayama $Y$, Viñuela $F$, Ulhoa $A$, Akiba $Y$, Vinters HV, Duckwiler GR, Gobin YP, Greff RJ: Non-adhesive liquid embolic agent for neurovascular apprications: Preliminary histopathological studies in swine rete mirabile. Neurosurgery 43: 1164-1175, 1998.

13) Murayama $Y$, Suzuki $Y$, Viñuela F, Kaibara M, Korotobi K, Iwaki M, Abe T: Development of a bioactive Guglielmi detachable coil for the treatment of the cerebral aneurysms. Parft I : In vitro Study. AJNR Am J Neuroradiol 20: 1986-1991, 1999.

14) Murayama Y, Viñuela F, Suzuki Y, Akiba Y, Duckwiler GR, YP Gobin, Abe T: Development of a bioactive Guglielmi detachable coil for the treatment of the cerebral aneurysms. Part II : Experimental study in a swine model. AJNR Am J Neuroradiol 20:1992-1999, 1999.

15) Murayama $Y$, Viñuela $F$, Tateshima $S$, Vinuela $F$ Jr, Akiba $\mathrm{Y}$ : Endovascular treatment of experimental aneurysms in use of a combination of liquid embolic agent and protection devices. AJNR Am J Neuroradiol 21:1726-1735, 2000.

16) Murayama $Y$, Viñuela F, Tateshima S, Song JK, Gonzalez $\mathrm{N}$, Wallace MP: Bioabsorbable polymeric material coils for embolization of intracranial aneurysms: A preliminary experimental study. J Neurosurg 94:454-463, 2001.

17) Murayama $Y$, Viñuela F, Tateshima S, Gonzalez NR, Song $\mathrm{JK}$, Mahdavieh $\mathrm{H}$, Iruela-Arispe L: Cellular responses of bioabsorbable polymeric material and Guglielmi detachable coil in experimental aneurysms. Stroke 33:1120$1128,2002$.

18) Murayama $Y$, Tateshima S, Gonzalez NR, Viñuela F: Matrix and bioabsorbable polymeric coils accelerate healing of intracranial aneurysms: Long-term experimental study. Stroke $\mathbf{3 4}:$ 2031-2037, 2003.

19) Murayama, $Y$, Saguchi $T$, Ishibashi T, Ebara M, Takao H, Irie $\mathrm{K}$, Ikeuchi $\mathrm{S}$, Onoue $\mathrm{H}$, Ogawa $\mathrm{T}$, Abe $\mathrm{T}$ : Endovascular operative suite: Future directions for treating neurovascular disease. J Neurosurg 104: 925-930, 2006.

20) Murayama Y, Viñuela, Ishii A, Nien YL, Yuki I, Duckwiler GR, Jahan R: Initial clinical experience with matrix detachable coils for the treatment of intracranial aneurysms. J Neurosurg 105: 192-199, 2006.

21) Takao H, Murayama Y, Ebara M, Ishibashi T, Saguchi T, Irie K, Yoshioka $\mathrm{H}$, Mori Y, Viñuela F, Abe T: New thermoreversible liquid embolic agent for embolotherapy. Technical report. Neuroradiology 51: 95-98, 2009.

22) Takao H, Murayama Y, Yuki I, Ishibashi T, Ebara M, Irie K, Yoshioka H, Mori Y, Viñuela F, Abe T: Endovascular treatment of experimental aneurysms using a combination of thermoreversible gelation polymer and protection devices: Feasibility study. Neurosurgery $65: 601-609$, 2009.

23) Yuki I, Lee D, Murayama Y, Chiang A, Vinters HV, Nismmura I, Wang CJ, Ishii A, Wu BM, Viñuela F : Thrombus organization and healing in an experimental aneurysm model. Part II. The effect of various types of bioactive bioabsorbable polymeric coils. J Neurosurg 107: 109-120, 2007. 
要旨

国際的視野をもつ脳神経外科医になるために

村山 雄一

われわれが目指すよりよい医療を実現するために，国際的な協力, コラボレーションが必要である が，異なる文化背景を有する研究者，あるいは他分野の研究者の考えを理解し尊重することが成功の ために不可欠である，本稿では，将来国際的視野をもった脳神経外科医を目指す若手医師が身につけ るべき要素について検討する.

脳外誌 $19: 395-401,2010$ 